Primljen / Received: 26.5.2016. Ispravljen / Corrected: 13.7.2017.

Prihvaćen / Accepted: 8.11.2017. Dostupno online / Available online: 10.4.2018.

\section{Effect of fly-ash based geopolymer coated aggregate on bituminous mixtures}

Authors:

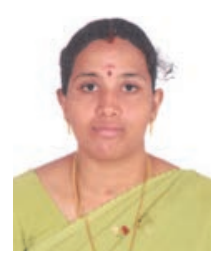

Assist.Prof. Srividya Dayal, PhD. CE Thiagarajar College of Engineering Department of Civil Engineering Tamilnadu, India vidyakrishna2006@gmail.com

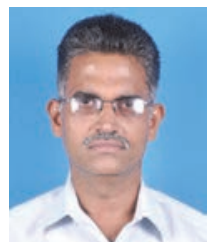

Assoc.Prof. Nagan Soundarapandian, PhD. CE Thiagarajar College of Engineering Department of Civil Engineering Tamilnadu, India nagan civil@tce.edu
Scientific Paper - Preliminary report

\section{Srividya Dayal, Nagan Soundarapandian}

Effect of fly-ash based geopolymer coated aggregate on bituminous mixtures

The research presented in the paper is conducted to evaluate properties of fly ashbased geopolymer coated aggregates and their effect on characteristics of bituminous mixtures. The investigation included aggregate testing, scanning electron microscope (SEM) analysis of fly ash and fly ash-based geopolymer, Marshall mix design, indirect tension test, dynamic shear rheometer (DSR) test for rheology, and repeated load test on bituminous mixtures with fly ash-based geopolymer coated aggregates.

Key words:

fly ash-based geopolymer, coated aggregate, bituminous mixtures, scanning electron microscope

Prethodno priopćenje

Srividya Dayal, Nagan Soundarapandian

Utjecaj agregata obloženog geopolimerom s letećim pepelom na bitumenske mješavine

Istraživanje prikazano u radu provedeno je u svrhu određivanja svojstava agregata obloženog geopolimerom na bazi letećeg pepela i utjecaja tih svojstava na karakteristike bitumenskih mješavina. Provedeno je ispitivanje agregata, analiza letećeg pepela i geopolimera na bazi letećeg pepela mikroskopom za elektronsko skeniranje (SEM), ispitivanje mješavina Marshallovom metodom, indirektno vlačno ispitivanje, ispitivanje reologije reometrom s dinamičkim smicanjem (DSR) te ispitivanje bitumenskih mješavina s agregatom obloženim geopolimerom na bazi letećeg pepela opetovanim opterećenjem.

Ključne riječi:

geopolimer na bazi letećeg pepela, obloženi agregat, bitumenske mješavine, mikroskop za elektronsko skeniranje

Vorherige Mitteilung

Srividya Dayal, Nagan Soundarapandian

Einfluss des mit Geopolymer beschichteten Zuschlagsstoffs mit Flugasche auf Bitumenmischungen

Die in der Abhandlung dargelegte Untersuchung wurde zum Zwecke der Bestimmung der MerkmaledesmitGeopolymeraufFlugaschebasisbeschichtetenZuschlagstoffsdurchgeführt sowie des Einflusses dieser Merkmale auf die Eigenschaften von Bitumenmischungen. Durchgeführt wurde eine Untersuchung des Zuschlagstoffs, eine Analyse der Flugasche und des Geopolymers auf Flugaschebasis mithilfe eines Rasterelektronenmikroskops (SEM), eine Untersuchung der Mischungen mithilfe der Marschall-Methode, ein indirekter Zugversuch, eine Untersuchung der Rheologie mit einem dynamischen Scher-Rheometer (DSR) sowie eine Untersuchung der Bitumenmischungen mit dem mit Geopolymer auf Flugaschebasis beschichteten Zuschlagsstoff durch wiederholte Belastung.

Schlüsselwörter:

Geopolymer auf Flugaschebasis, beschichteter Zuschlagsstoff, Bitumenmischungen, Rasterelektronenmikroskop 


\section{Introduction}

India, as a developing country, is presently facing high demand for good quality aggregates for infrastructure development and, on the other end, it is burdened with problems of utilization and disposal of fly ash, generated from coal-fired thermal power plants.

A report presented in 2006 by the US based Freedonia Group (Worlds Construction Aggregates, 2007) [1] revealed that there is $30-35 \%$ demand for aggregates in non-residential buildings, $25 \%$ demand for highways, and $25 \%$ for housing, and that this trend is expected to increase. Patrick Smith reported in 2013 (Aggregate Business International) [2] that the global market for construction aggregates is expected to grow by $5.2 \%$ per year until 2015 to 48.3 billion tonnes. In India, the demand for construction aggregates is expected to increase by $8.5 \%$ per year to 3.3 billion tonnes until 2015, and 5 billion tonnes until 2020, which represents the fastest growth rate compared to any nation worldwide.

In addition, according to the Central Electricity Authority report dated 31.3.2011, 54.09\% of total electricity produced in India is currently generated in coal based thermal power plants. The maximum utilization of fly ash is reported in cement sector $(48.13 \%)$, while $13.02 \%$ is used in roads and embankments. Overall, approximately $55.69 \%$ of fly ash generated in 2014-15 is used in the country. Coal requirement and generation of fly ash estimated for the year 2031-2032 is around 1800 million tons and 600 million tons, respectively. Ninety-five million tons of fly ash are generated every year, and this quantity of fly ash occupies approximately 65,000 acres of land (Ministry of Science and Technology, India, 2010).

Additional literature was reviewed with the objective of finding solutions to demand for aggregates and utilisation of fly ash.

\subsection{Fly ash in bituminous mixes}

A number of papers have described application of fly ash in highway embankments. Extensive research has been carried out by various researchers throughout the world regarding the use of fly ash in bituminous mixes. Many studies have shown that fly ash as filler material in bituminous mixes is more resistant to low temperatures, tensile stress, fatigue cracking, and water action, Kumar et al. [3], Vishal Sharma et al. [4], and M.N. Rahman et al. [5]. A study made by Suheibani [6] revealed that addition of class $F$ fly ash in bituminous concrete provides superior indirect tensile strength, rut resistance, and fatigue life. Following micro structural investigations of asphalt binders modified with fly ash, Sobolev et al. [7] concluded that the crack - arresting behaviour effect was successfully induced by fly ash particles evenly distributed in bitumen matrix. The research confirmed feasibility of using fly ash to improve the properties and performance of asphalt binders and mixtures. The research by Sobolev et al. [8] demonstrated that the addition of fly ash does not affect compatibility of asphalt mixtures, and that round particles of fly ash in asphalt help in reducing mixing and placing temperatures, while extending the workability of mixtures. Due to comparatively higher presence of calcium oxide in fly ash, the latter has better rutting potential, higher tensile strength ratio, retained stability and lower temperature strain. Tara Sen and Umesh Mishra [9] reported that the use of fly ash reduces the potential for asphalt stripping due to hydrophobic properties. Gordana et al. [10] concluded that the use of fly ash as filler material in asphalt mixtures results in higher concentration of binder.

\subsection{Fly ash-based geopolymer}

Geopolymers are inorganic materials that form a long-range, covalently bonded non crystalline skeleton. Raw materials used in the synthesis of silicon-based polymers are mainly rock-forming minerals of geological origin and hence Joseph Davidovits [11] developed the concept of fly ash-based geopolymer perceiving it as a dense amorphous phase consisting of semi crystalline three dimensional aluminosilicate microstructure. Vaan Jaarsveld et al. [12] investigated the facts of geopolymerisation and stated that, in some cases, the properties of geopolymeric materials are superior to existing cementitious materials. $\mathrm{Xu}, \mathrm{H}$ et al. [13] and Diaz et al. [14] found that the calcium content in fly ash has a significant effect on the properties of fresh geopolymer mixture and the hardened product, which may be the result of formation of hydrated calcium silicate compounds. Hongling Wang et al. [15] synthesized geopolymer from metakaolinite under activation of $\mathrm{NaOH}$ and sodium silicate solution, and studied the effect of $\mathrm{NaOH}$ on the properties of geopolymer. The study concluded that the density and strength of geopolymer concrete increase with an increase in $\mathrm{NaOH}$ concentration. Bakharev [16] investigated durability of geopolymer materials produced from $\mathrm{F}$ class fly ash and reported that the best performance could be exhibited by materials prepared in the sodium hydroxide medium when exposed to sulphate environment. Nevertheless, an effective use of fly ash based geopolymer in pavement construction is quite limited. This may be due to the lack of information on its engineering properties.

Bituminous concrete contains $90-95 \%$ of aggregate by weight. Therefore, the service life and performance of pavement largely depends on the quality of aggregate used for the construction, which in turn is a function of surface texture, particle size and shape and its mineralogical composition. With the declining availability of good quality aggregates, the life cycle cost can be economically balanced by utilizing locally available material. Taking this into account, this study investigates the properties of marginal aggregates collected from various quarry sites, which are enhanced by coating with fly ash-based geopolymer, and assesses the resulting effect on bituminous concrete. 


\section{Materials}

Two types of fly ash, sodium silicate and sodium hydroxide alkali medium (10 Molar concentration), are used in this study for the preparation of fly ash-based geopolymer. Broken stone from granite quarry sites is used as coarse aggregate. Bitumen grade VG 10 is used as binder in the preparation of bituminous concrete. The information on materials used, their source and testing, is provided in Table 1.

Table 1. Materials used for study

\begin{tabular}{|c|c|c|}
\hline Material & Source & Tests \\
\hline Fly ash (FA1) & $\begin{array}{l}\text { Tuticorin Thermal } \\
\text { Power plant }\end{array}$ & \multirow{2}{*}{$\begin{array}{l}\text { Chemical } \\
\text { Composition test, } \\
\text { SEM with EDAX }\end{array}$} \\
\hline Fly ash (FA2) & $\begin{array}{l}\text { Neyveli Lignite } \\
\text { Corporation }\end{array}$ & \\
\hline $\begin{array}{l}\text { Chemicals - Sodium } \\
\text { Silicate and Sodium } \\
\text { Hydroxide }\end{array}$ & Local supplier & $\begin{array}{l}\text { Check for its purity } \\
\text { (packaging details) }\end{array}$ \\
\hline $\begin{array}{l}\text { Fly ash-based } \\
\text { geopolymer }\end{array}$ & $\begin{array}{l}\text { Laboratory } \\
\text { preparation }\end{array}$ & Workability tests \\
\hline $\begin{array}{l}\text { Coarse Aggregates - } \\
\text { uncoated (plain) }\end{array}$ & $\begin{array}{l}\text { Different granite } \\
\text { quarry sites }\end{array}$ & \multirow{2}{*}{$\begin{array}{l}\text { Physical tests - } \\
\text { Specific gravity, } \\
\text { water absorption } \\
\text { and combined index } \\
\text { Mechanical test - } \\
\text { Impact, crushing, } \\
\text { abrasion and } \\
\text { stripping value test }\end{array}$} \\
\hline $\begin{array}{l}\text { Coarse Aggregates } \\
\text { - Fly ash-based } \\
\text { geopolymer coated } \\
\text { aggregates }\end{array}$ & $\begin{array}{l}\text { Laboratory } \\
\text { preparation }\end{array}$ & \\
\hline Bitumen (VG10) & $\begin{array}{l}\text { Local supplier near } \\
\text { Thirumanagalam }\end{array}$ & $\begin{array}{l}\text { Softening point, } \\
\text { ductility, penetration } \\
\text { and viscosity test }\end{array}$ \\
\hline
\end{tabular}

\subsection{Fly ash}

Fly ash obtained from Tuticorin Thermal Power plant (FA1) and Neyveli Lignite Corporation (FA2) is heterogeneous in nature and greyish white in colour. FA1 contains $1.6 \%$ sulphur trioxide by mass and free $\mathrm{CaO}$, and is designated as class F fly ash as per ASTM C618. The content of available alkali in form of sodium oxide amounts to $1.23 \%$ by mass. The specific gravity of fly ash FA1 is 1.8 , and $90 \%$ of fly ash passes through the $45 \mu \mathrm{m}$ sieve. The content of silica and calcium oxide in fly ash FA2 is $35.23 \%$ and $9.09 \%$ by mass, respectively. The specific gravity is 1.76 , and $95 \%$ of material passes through the $45 \mu \mathrm{m}$ sieve. Chemical composition of fly ash is presented in Table 2.
Table 2. Chemical Composition of Fly ash

\begin{tabular}{|l|c|c|}
\hline Component & FA 1 & FA 2 \\
\hline $\begin{array}{l}\text { Silicon dioxide }\left(\mathrm{SiO}_{2}\right) \text { plus aluminium oxide (AI2O3) } \\
\text { plus Iron oxide }\left(\mathrm{Fe}_{2} \mathrm{O}_{3}\right) \text {. percent by mass }\end{array}$ & 81.49 & 76.97 \\
\hline Silica (as $\left.\mathrm{SiO}_{2}\right)$. percent by mass & 52.03 & 35.23 \\
\hline Magnesium oxide (as MgO). percent by mass & 3.27 & 4.15 \\
\hline $\begin{array}{l}\text { Total sulphur as sulphur trioxide }\left(\mathrm{SO}_{3}\right) \text {. percent by } \\
\text { mass }\end{array}$ & 1.60 & 3.53 \\
\hline Loss on ignition & 2.59 & 4.75 \\
\hline
\end{tabular}

\subsection{Alkaline liquids}

The silicates and hydroxides of the water soluble high alkaline sodium were used in this study. The sodium silicate (Na2SiO3) and Sodium hydroxide $(\mathrm{NaOH})$, which is also known as caustic soda, in flake form with $98 \%$ purity, was purchased in bulk from a local supplier. The hydroxide solution required for complete activation was prepared to a concentration of $10 \mathrm{M}$ by adding 10 X $40=400$ grams of $\mathrm{NaOH}$ flakes in one litre of distilled water, where 40 is the molecular weight of $\mathrm{NaOH}$. The properties of geopolymer change with an increase in the concentration of alkali medium. For FA1, workability tests were carried out at $8 \mathrm{M}, 10 \mathrm{M}, 12 \mathrm{M}, 14 \mathrm{M}$, and $16 \mathrm{M}$ concentrations of $\mathrm{NaOH}$, but for FA2, workability tests were conducted at 15M, 22M, and 29M.

\subsection{Fly ash-based geopolymer}

Geopolymers are members of the family of inorganic polymers. The geosynthesis reaction between any pozzolanic compound or source of silica and alumina in the alkaline medium lends to geopolymerisation which yields three-dimensional polymeric chain of Si-O-Al bonds (Joseph Davidovits, 1988) [11].

Various literature data on geopolymer paste show that the properties of geopolymer are highly affected by the concentration of $\mathrm{NaOH}$. Trail mixes were prepared for different workability of fly ash-based geopolymer paste to achieve a correct proportion of fly ash, sodium silicate and sodium hydroxide. The corresponding results are presented in Table 3 and Table 4. Fly ash was sieved using a $45 \mu \mathrm{m}$ sieve. $\mathrm{NaOH}$ solution was prepared 24 hours before it was used for preparation of geopolymer. Sodium silicate pellets were dissolved in $\mathrm{NaOH}$ solution 4 hours before fly ash was added, and mixing was operated for 3 minutes. The ratio of sodium silicate to $\mathrm{NaOH}$ was kept in the range of 0.5 to 0.4 , so that this fly ash-based geopolymer paste can be used for coating the coarse aggregate. Geopolymer paste was prepared by slowly adding a weighed amount of fly ash (FA1) to the alkaline solution, and the mixing was conducted by means of a mechanical stirrer for 8 min to reach proper consistency as suggested by Temuujin at al. [17]. Geopolymer with FA2 was prepared in the same manner. Since FA2 contained a somewhat higher amount of $\mathrm{CaO}, 15$ minutes of mixing was needed to reach the required consistency. 


\subsubsection{Workability}

The workability of the fly ash-based geopolymer paste was examined using the Marsh cone method, and also by means of the flow table test as suggested by Debabrata Dutta in 2012 [18]. The Marsh cone is a flow cone with an aspect ratio of 2:1 and a working volume of at least a litre. It consists of a cone 6 inches $(152 \mathrm{~mm})$ across and 12 inches $(305 \mathrm{~mm})$ in height equipped at its apex with a tube 2 inches $(50.8 \mathrm{~mm})$ long and $3 / 16$ inch $(4.76 \mathrm{~mm})$ in internal diameter. A 10 -mesh screen is fixed near the top across half the cone. The geopolymer paste was prepared for various molarities of sodium hydroxide. It was made sure that no water was added. The geopolymer paste was poured into the Marsh cone and the time of flow of $240 \mathrm{ml}$ of paste was measured in seconds 30 seconds after preparation.

In the flow table experiment setup, a bronze cylinder $6 \mathrm{~cm}$ in diameter and $8 \mathrm{~cm}$ in height was used as a mould to hold the geopolymer paste. The flow table $50 \mathrm{~cm}$ in outer diameter features 50 equally spaced concentric circles. The mould was placed at the exact centre of the flow table making sure that its centre coincides with the centre of the flow table. After filling the mould with geopolymer paste, it was moved up slowly, ensuring that it was raised vertically, thus allowing the paste to flow. The flow diameter and area were measured after the flow had stopped. The workability results for geopolymer paste prepared with FA1 and FA2 are presented in Table 3 and Table 4 , respectively.

The workability tests results were used to achieve an appropriate proportion of ingredients for the preparation of the fly ash-based geopolymer. It was observed that the fluidity of the geopolymer prepared with both types of fly ash decreases with an increase in $\mathrm{NaOH}$ concentration. The flow $(\mathrm{mm})$ decreases with the higher molarity of $\mathrm{NaOH}$, thus making the geopolymer paste a hard mix. For further study, the ratio of sodium silicate to sodium hydroxide and alkali activator to fly ash content was kept at 0.4 for the fly ash-based geopolymer prepared with FA1. To maintain the same consistency, the 0.35 ratio of sodium silicate to sodium hydroxide was used, and the alkali activator to fly ash content was kept at 0.4 for the fly ash-based geopolymer prepared with FA2.

Table 3. Workability of geopolymer with fly ash FA1

\begin{tabular}{|c|c|c|c|c|c|c|c|c|c|c|c|}
\hline \multirow{2}{*}{$\begin{array}{l}\text { Sodium silicate/ } \\
\text { sodium hydroxide }\end{array}$} & \multirow{2}{*}{$\begin{array}{l}\text { Activator / } \\
\text { fly ash }\end{array}$} & \multicolumn{5}{|c|}{ Marsh cone flow value [s] } & \multicolumn{5}{|c|}{ Flow table value $[\mathrm{mm}]$} \\
\hline & & $8 \mathrm{M}$ & $10 M$ & $12 M$ & $14 \mathrm{M}$ & $16 \mathrm{M}$ & $8 \mathrm{M}$ & $10 M$ & $12 \mathrm{M}$ & $14 M$ & $16 \mathrm{M}$ \\
\hline \multirow{5}{*}{0.5} & 0.6 & 394 & 406 & 414 & 506 & 656 & 181 & 175 & 168 & 123 & 114 \\
\hline & 0.55 & 434 & 447 & 456 & 548 & 688 & 169 & 166 & 157 & 134 & 112 \\
\hline & 0.5 & 473 & 489 & 497 & 583 & 717 & 162 & 154 & 145 & 127 & 107 \\
\hline & 0.45 & 523 & 532 & 540 & 611 & 747 & 148 & 141 & 132 & 119 & 98 \\
\hline & 0.4 & 568 & 577 & 583 & 638 & 769 & 124 & 127 & 116 & 102 & 87 \\
\hline \multirow{5}{*}{0.46} & 0.6 & 351 & 372 & 381 & 496 & 648 & 209 & 197 & 189 & 153 & 124 \\
\hline & 0.55 & 398 & 413 & 422 & 540 & 678 & 197 & 188 & 178 & 141 & 120 \\
\hline & 0.5 & 436 & 455 & 464 & 562 & 684 & 191 & 175 & 165 & 132 & 118 \\
\hline & 0.45 & 482 & 498 & 507 & 589 & 711 & 179 & 163 & 153 & 126 & 103 \\
\hline & 0.4 & 496 & 524 & 543 & 597 & 734 & 163 & 148 & 144 & 117 & 85 \\
\hline \multirow{5}{*}{0.42} & 0.6 & 340 & 348 & 356 & 472 & 612 & 234 & 226 & 223 & 173 & 157 \\
\hline & 0.55 & 381 & 389 & 397 & 513 & 649 & 221 & 214 & 211 & 167 & 149 \\
\hline & 0.5 & 420 & 431 & 439 & 540 & 694 & 219 & 201 & 198 & 136 & 132 \\
\hline & 0.45 & 453 & 474 & 482 & 565 & 707 & 201 & 188 & 187 & 122 & 104 \\
\hline & 0.4 & 479 & 502 & 503 & 592 & 746 & 189 & 162 & 168 & 112 & 89 \\
\hline \multirow{5}{*}{0.4} & 0.6 & 292 & 316 & 327 & 357 & 507 & 263 & 248 & 239 & 183 & 169 \\
\hline & 0.55 & 331 & 357 & 368 & 391 & 530 & 251 & 239 & 227 & 176 & 154 \\
\hline & 0.5 & 372 & 399 & 410 & 398 & 548 & 246 & 227 & 216 & 169 & 131 \\
\hline & 0.45 & 418 & 442 & 453 & 414 & 564 & 223 & 214 & 203 & 152 & 125 \\
\hline & 0.4 & 440 & 456 & 475 & 445 & 589 & 204 & 197 & 191 & 133 & 113 \\
\hline
\end{tabular}


Table 4. Workability of geopolymer with fly ash FA2

\begin{tabular}{|c|c|c|c|c|c|c|c|}
\hline \multirow{2}{*}{$\begin{array}{l}\text { Sodium silicate/ } \\
\text { sodium hydroxide }\end{array}$} & \multirow{2}{*}{$\begin{array}{l}\text { Activator / } \\
\text { fly ash }\end{array}$} & \multicolumn{3}{|c|}{ Marsh cone flow value [s] } & \multicolumn{3}{|c|}{ Flow table value $[\mathrm{mm}]$} \\
\hline & & $15 M$ & $22 \mathrm{M}$ & $29 M$ & $15 \mathrm{M}$ & $22 \mathrm{M}$ & $29 M$ \\
\hline \multirow{5}{*}{0.45} & 0.6 & 360 & 384 & 408 & 160 & 143 & 137 \\
\hline & 0.55 & 388 & 409 & 444 & 149 & 136 & 157 \\
\hline & 0.5 & 432 & 445 & 473 & 123 & 124 & 145 \\
\hline & 0.45 & 492 & 507 & 548 & 103 & 99 & 132 \\
\hline & 0.4 & 518 & 536 & 579 & 94 & 87 & 116 \\
\hline \multirow{5}{*}{0.4} & 0.6 & 334 & 355 & 385 & 187 & 179 & 159 \\
\hline & 0.55 & 371 & 386 & 402 & 167 & 157 & 148 \\
\hline & 0.5 & 418 & 447 & 469 & 151 & 145 & 137 \\
\hline & 0.45 & 453 & 474 & 493 & 129 & 121 & 117 \\
\hline & 0.4 & 494 & 512 & 531 & 113 & 107 & 98 \\
\hline \multirow{5}{*}{0.35} & 0.6 & 289 & 319 & 334 & 213 & 192 & 188 \\
\hline & 0.55 & 331 & 377 & 364 & 197 & 181 & 171 \\
\hline & 0.5 & 369 & 399 & 423 & 181 & 173 & 169 \\
\hline & 0.45 & 398 & 445 & 463 & 167 & 153 & 146 \\
\hline & 0.4 & 437 & 472 & 490 & 144 & 128 & 114 \\
\hline
\end{tabular}

\subsubsection{SEM analysis}

The scanning electron microscopy (SEM) was performed to gain a better insight into the morphology of fly ash and fly ash-based geopolymer. The SEM is used to produce microscopic images with high resolution to show the difference in the reacting region and chemical composition. The SEM-EDAX test was performed on the fly ash and fly ash-based geopolymer samples prepared in the alkaline medium with the 10-molar concentration of sodium hydroxide. Images (Figure 4a and 4b) of the fly ash-based geopolymer show the microstructure exhibiting more and close unreacted and partly unreacted particles. Major elements observed from the EDAX spectra of fly ash are oxygen (O), silicon (Si), sodium (Na), calcium (Ca), aluminium (Al) with traces of magnesium $(\mathrm{Mg})$, potassium (K), titanium (Ti), and iron (Fe). But the EDAX spectra of geopolymer show major elements with an increase in weight percentages of oxygen (O), aluminium (Al), silicon (Si), and calcium (Ca). However, traces of sodium (Na) and potassium (K) were not found. Thus, it could be concluded that sodium silicates and sodium hydroxide fully participated
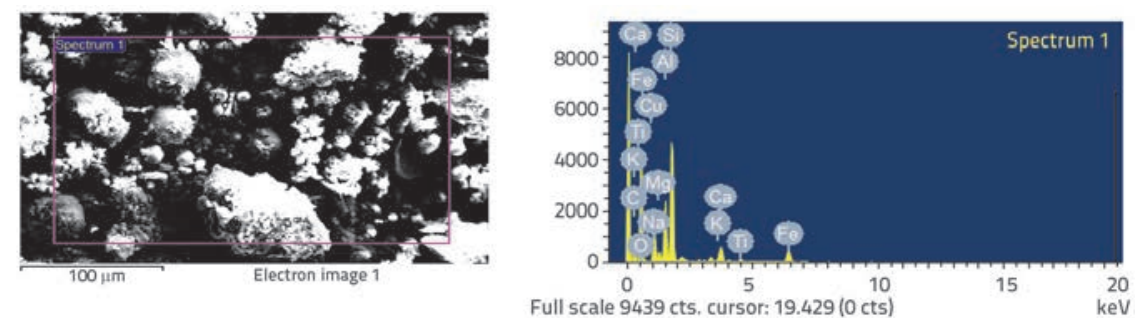

Figure 1. a) SEM image of FA1; b) EDAX image of FA1
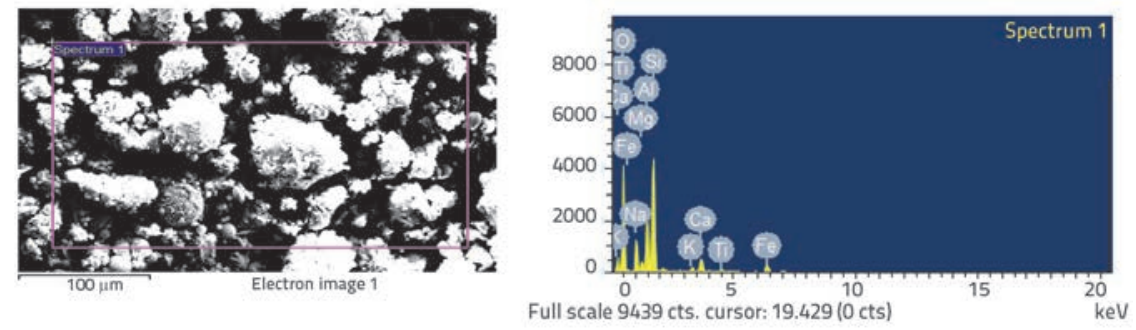

Slika 2. a) SEM image of FA2; b) EDAX image of FA2
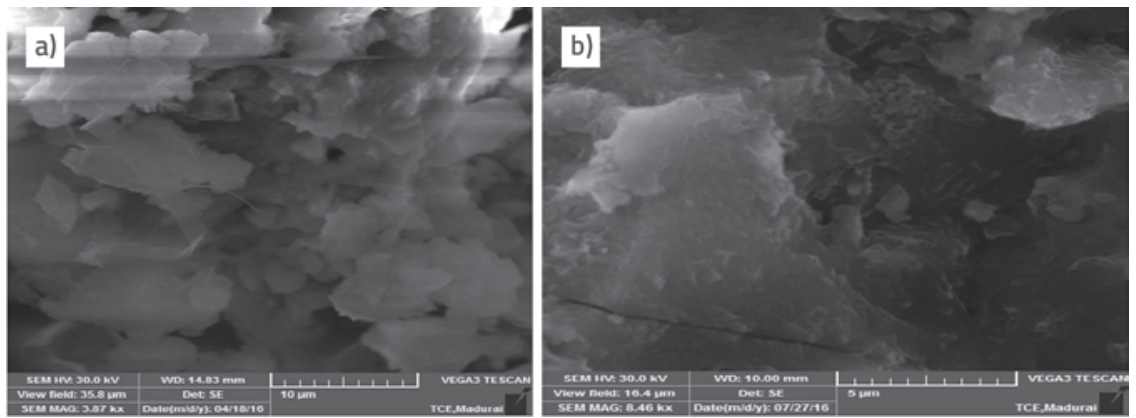

Figure 3. a) a) SEM image of FA1 geopolymer (10M); b) SEM image of FA2 geopolymer (15M) 
in the polymerization process. The SEM images of fly ash samples FA1 and FA2 are presented in Figure 2.a and Figure3.a. Microscopic images of the fly ash-based geopolymer prepared using FA1 and FA2 are shown in Figure 4.a and Figure 4.b, respectively. The SEM micrographs revealed that the amount of calcium leads to the formation of calcium silicates in addition to geopolymer gel products (Xueying at al., 2013) [19].

\subsection{Coarse aggregate}

The quality, strength and durability of aggregates play a vital role in the design of bituminous mixes. These qualities minimize the rate of disintegration and maximize stability of compacted material. Even though the use of locally available materials could be economical, it may not be always practicable because available aggregates do not sometimes meet quality requirements specified for pavement mixtures.

\section{Plain (uncoated) aggregate}

Broken stone material was collected from three different granite quarry sites near Madurai city, crushed to the desired sizes, and used as coarse aggregate. Together they were treated as coarse aggregates from a single source. These locally available materials were found to be marginal aggregates.

\section{Fly ash-based geopolymer coated aggregates}

Much research has been performed using a number of methods for aggregate treatment, e.g. for aggregate blending, impregnation, coating with organic polymers, etc. The concept of natural aggregate coating is hence not of recent origin. Bayomi [20] suggested the concept of coating natural aggregate with ordinary Portland cement, which improved adhesion of bitumen binder to the surface of the aggregate, thus increasing strength of the bituminous mixture and its resistance to deformation. Kamaruddin et al. [21] investigated cement-coated aggregate asphaltic concrete and concluded that the treated mixes attained highest stiffness and showed better resistance to deformation.

As fly ash-based geopolymers are well known alternate binders for cement, this study was carried out to investigate the use of fly ash-based geopolymer coated aggregates in bituminous concrete mixtures.

The objective of aggregate coating with geopolymer was to apply a geopolymer layer that is thick enough to cover the surface of the aggregate, without sticking to other particles and forming lumps. It was ensured that the fly ash-based geopolymer paste is prepared as discussed in Section 2.3. A proper consistency was also maintained. Aggregates for coating with the fly ashbased geopolymer should preferably be hot. In fact, at lower temperatures, the fly ash-based geopolymer fails to adhere completely onto the surface of the aggregates. Therefore, $140^{\circ} \mathrm{C}$ was taken to be a minimum aggregate temperature for coating. This procedure needed to be performed with a minimum amount of flaws to enable further testing of aggregates. Thus, the pan mixer was employed to ensure a uniform aggregate coating. The texture of the uncoated crushed aggregates and coated aggregates is shown in Figure 4.

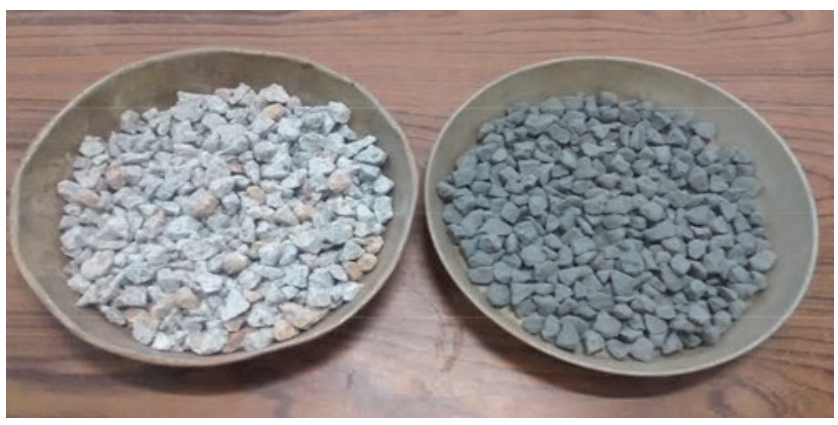

Figure 4. Uncoated and fly ash-based geopolymer coated aggregates

Physical and mechanical properties of aggregates were tested for the crushed white granite aggregates with and without coating with the fly ash-based geopolymer. The coated aggregates were prepared by geopolymer for FA1 with $10 \mathrm{M}$ of $\mathrm{NaOH}$, and for FA2 with $15 \mathrm{M}$ of $\mathrm{NaOH}$. Furthermore, in this study CA-FA1 and CA-FA2 represent coated aggregates with fly ash-based geopolymer with FA1 and FA2, respectively. The specification provided by the Ministry of Road Transport and Highways (MoRTH, India, 2004) was used for assessing suitability of using treated aggregates in pavement structures.

\subsubsection{Physical properties}

Specific gravity, water absorption property, particle shape and size, are considered to be highly important in the design of bituminous mixtures. These tests were carried out as per IS 2386. Higher specific-gravity values could be found for fly ash-based geopolymer coated aggregates. Table 5 shows that there is no significant change in water absorption and combined index for coated aggregates. This could possibly be due to the presence of $\mathrm{CaO}$ and dense unreacted particles in the geopolymer but, since values are within the specified limits, the aggregates are still considered suitable for road construction.

Table 5. Physical properties of aggregates

\begin{tabular}{|c|c|c|c|c|c|}
\hline Test & $\begin{array}{c}\text { Uncoated } \\
\text { aggregates }\end{array}$ & $\begin{array}{c}\text { CA- FA1 } \\
\text { (10M) }\end{array}$ & $\begin{array}{c}\text { CA- FA2 } \\
\text { (15M) }\end{array}$ & Standard & $\begin{array}{c}\text { MoRTH } \\
\text { specification }\end{array}$ \\
\hline $\begin{array}{c}\text { Specific } \\
\text { gravity }\end{array}$ & 2.59 & 2.62 & 2.64 & $\begin{array}{c}\text { IS 2386 } \\
\text { Part III }\end{array}$ & $2.5-3.0$ \\
\hline $\begin{array}{c}\text { Water } \\
\text { absorption } \\
{[\%]}\end{array}$ & 0.71 & 0.55 & 0.61 & $\begin{array}{c}\text { IS 2386 } \\
\text { Part III }\end{array}$ & $\max 2$ \\
\hline $\begin{array}{c}\text { Combined } \\
\text { index [\%] }\end{array}$ & 22.34 & 22.76 & 22.81 & $\begin{array}{c}\text { IS 2386 } \\
\text { Part I }\end{array}$ & $\operatorname{max~35}$ \\
\hline
\end{tabular}


Table 6. Mechanical properties of aggregates

\begin{tabular}{|c|c|c|c|c|c|}
\hline Test & $\begin{array}{c}\text { Uncoated } \\
\text { aggregates }\end{array}$ & $\begin{array}{c}\text { CA- FA1 } \\
\text { (10M) }\end{array}$ & $\begin{array}{c}\text { CA- FA2 } \\
\text { (15M) }\end{array}$ & Standard & MoRTH specification \\
\hline Impact value $[\%]$ & 33.31 & 23.38 & 23.55 & $\begin{array}{l}\text { IS } 2386 \\
\text { Part IV }\end{array}$ & $\max .24$ \\
\hline Crushing value [\%] & 32.00 & 25.43 & 22.45 & $\begin{array}{l}\text { IS } 2386 \\
\text { Part IV }\end{array}$ & maxs. 24 \\
\hline Abrasion (Los Angeles) [\%] & 32.25 & 33.77 & 33.75 & $\begin{array}{l}\text { IS } 2386 \\
\text { Part IV }\end{array}$ & $\max .30$ \\
\hline Stripping value & More than 95 & & & IS 6241 & Min retained coating 95 \\
\hline
\end{tabular}

\subsubsection{Mechanical Properties}

The aggregate crushing value, Impact value, and Los Angeles abrasion, were tested to determine mechanical strength of the aggregates. The results of these tests are presented in Table 6. Comparatively better results were achieved for aggregates coated with geopolymer prepared with FA2. This could be possibly due to higher content of $\mathrm{CaO}$ and formation of calcium silicates, and penetration into aggregate pores, as studied by Temuujin. J et al. (2010) [17].

\subsection{Binder}

Bitumen grade VG10 was used as binder material. The binder was tested for its physical properties and the corresponding test results confirmed compliance with requirements as per IS: 73-2006. Bitumen properties are presented in Table 7.

Table 7. Binder properties

\begin{tabular}{|l|c|}
\hline Property & Value \\
\hline $\begin{array}{l}\text { Penetration at } 25^{\circ} \mathrm{C}(1 / 10 \text { th of mm, Standard } \\
\text { Penetrometer) }\end{array}$ & 86 \\
\hline Softening point (Ring and Ball Apparatus) [ $\left.{ }^{\circ} \mathrm{C}\right]$ & 40 \\
\hline Ductility at $27^{\circ} \mathrm{C}[\mathrm{cm}]$ & $>100$ \\
\hline Specific gravity & 1.05 \\
\hline Viscosity (Brookfield Viscometer), $135^{\circ} \mathrm{C}\left[\mathrm{N} / \mathrm{mm}^{2}\right]$ & 0.533 \\
\hline
\end{tabular}

\section{Aggregate gradation and mix design}

\subsection{Aggregate gradation}

Aggregate gradation is the most important parameter that directly and significantly affects properties of bituminous mixtures. Investigation by Y.R. Kim et al., [22] reveals that medium gradation provides better resistance to rutting. $\mathrm{K}$. Kantha Kumar and A. Veeraragavan [23] consider that, for the bituminous concrete mixture, the uppermost gradation line above three fourth is an optimum ensuring maximum fatigue life. The broken granite stone material collected from quarry was crushed into desired sizes of $25 \mathrm{~mm}, 12 \mathrm{~mm}, 10 \mathrm{~mm}$, and $6 \mathrm{~mm}$, and the dust was produced by crusher. Sieve analysis was performed to obtain desired gradation that had to match the MoRTH specification for Grade I Bituminous Concrete (BC) mix. The aggregate gradation adopted for the study is presented in Figure 5.

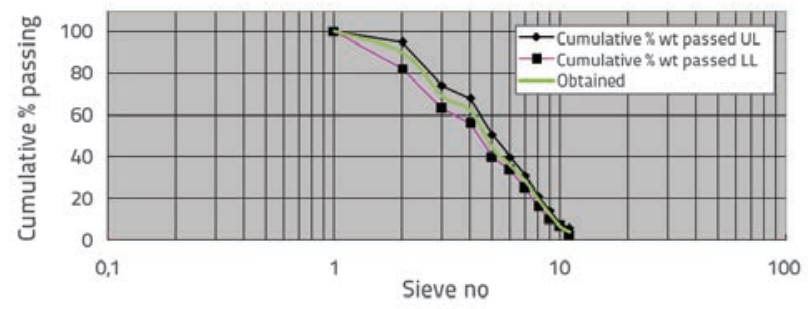

Figure 5. Aggregate gradation for BC Grade 1

\subsection{Mix design by Marshall stability method}

Cylindrical specimens $101.6 \mathrm{~mm}$ in diameter and $63.5 \mathrm{~mm}$ in thickness were prepared for the aggregate gradation selected according to ASTM D6926 in order to study the effect of using fly ash-based geopolymer coated aggregates in bituminous concrete mixtures. The Marshall mix design method recommended in Indian specification for the design of bituminous mixes and MoRTH specification, Government of India (2004), was used in the present study. Three types of bituminous concrete mixes for BC Grade I were prepared and tested for Marshall flow properties.

- Type I BC mix with uncoated (plain) aggregates,

- Type II BC mix with fly ash-based geopolymer coated aggregates with FA1, and

- Type III BC mix with fly ash-based geopolymer coated aggregates with FA2.

To prepare the Type II and Type III mixes, the coated aggregates were prepared as discussed in Sections 2.3 and 2.4.

Coated aggregates were then mixed with hot bitumen (heated to $160^{\circ} \mathrm{C}$ ). The mixing temperature was maintained 
between $150^{\circ}$ and $160^{\circ} \mathrm{C}$ and 75 blows were applied on each side on the specimens varying in bitumen content. The compaction temperature was kept in the range of $95^{\circ}$ C to $110^{\circ} \mathrm{C}$. The cylindrical specimens were then subjected to the Marshall stability and flow test as per ASTM D6927. The maximum load at failure was recorded when specimens were compressed onto lateral surface at a uniform rate of $50.8 \mathrm{~mm}$ per minute. Void analysis was carried out for test specimens to determine an optimum binder content. The mix design criteria for grade 1 bituminous concrete specified by MoRTH is presented in Table 8.

Table 8. Mix design criteria for $\mathrm{BC}$ mix

\begin{tabular}{|l|c|}
\hline Marshall Mix Criteria & Limits \\
\hline Compaction (number of blows on each face) & 75 \\
\hline Stability, kN & 9 \\
\hline Flow, mm & 2 do 4 \\
\hline Percent of air voids & 3 do 5 \\
\hline Percent of voids filled with bitumen & 65 do 75 \\
\hline Percent of voids in mineral aggregates & min 13 \\
\hline
\end{tabular}

\subsection{Optimum binder content}

The tests were carried out on specimens with binder content in the mix varying between $4 \%$ to $7.0 \%$, with incremental values of $0.5 \%$. The only design criteria for an optimum binder content is that the percentage of voids should be within 3 to 5 . An optimum binder content for test specimens was evaluated using this criteria and maximum bulk specific gravities and maximum stability. It was established that the optimum binder content amounts to $4 \%$ voids. Test results for BC mixes are shown in Figure 6. Each point represents numerical mean of three specimens.

Bulk density at specified voids i.e. $4 \%$ maximum stability, can be seen in Figure 6. Studying the test results, it was found that an optimum binder content (OBC) required for the Type I and Type II mixes amounts to $5.5 \%$ for the selected gradation of aggregates. For the Type III mix, the design criteria could be satisfied at an optimum binder content of $5.8 \%$. This could be due to a higher amount of calcium oxide present in FA2, which leads to formation of calcium silicates and thus absorbs more binder, as reported by Md. Kamal Hussain in 2011 [24]. This design binder content was used in further study.

\subsection{Moisture susceptibility test}

Water is a major cause of premature failure of flexible pavements. Test were performed according to ASTM D 1075 test method to determine moisture susceptibility of bituminous mixes. This experiment was performed on specimens prepared
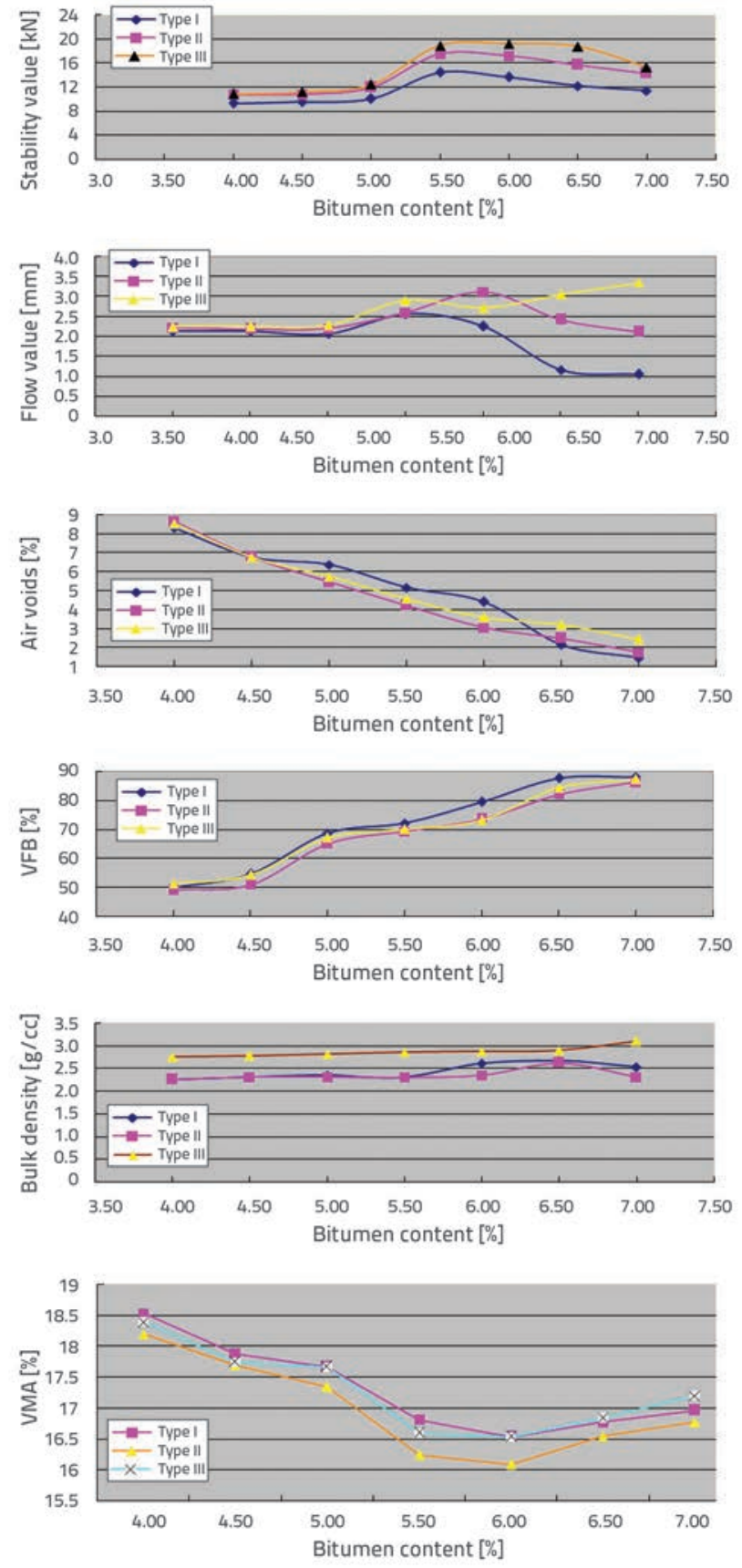

Figure 6. Properties of bituminous mixes

as in Marshall test, i.e. the specimens were grouped into types I, II and III. Six specimens in two three-specimen groups were prepared for each mix type. Group I was immersed for 4 hours at $25^{\circ} \mathrm{C}$, and group II was immersed for 24 hours at $60^{\circ} \mathrm{C}$, and 2 hrs at $25{ }^{\circ} \mathrm{C}$. The Marshall stability values were compared for the two groups, and the index of retained strength was determined. The results are shown in Table 9. The retained stability at optimum binder content was found to be more than $85 \%$ for type II and III bituminous mixes, which is an indicator of resistance to water action. 
Table 9. Retained stability value

\begin{tabular}{|c|c|c|c|c|}
\hline \multirow{2}{*}{$\begin{array}{c}\text { Bitumen } \\
\text { content } \\
{[\%]}\end{array}$} & \multirow{2}{*}{$\begin{array}{c}\text { Bitumen } \\
\text { mix }\end{array}$} & \multicolumn{2}{|c|}{$\begin{array}{c}\text { Stability value } \\
{[\mathrm{kN}]}\end{array}$} & \multirow{2}{*}{$\begin{array}{c}\text { Index of } \\
\text { retained } \\
\text { strength }\end{array}$} \\
\cline { 3 - 4 } & Group I & Group II & (10.45 & 0.73 \\
\hline 5.5 & Type I & 14.26 & 10.36 \\
\hline 5.5 & Type II & 16.78 & 14.37 & 0.86 \\
\hline 5.8 & Type III & 19.12 & 17.45 & 0.91 \\
\hline
\end{tabular}

\section{Tests on bituminous concrete and results}

Main laboratory tests of bituminous concrete mixtures included the indirect tension test, repeated load test, and dynamic shear rheometer test. The indirect tension test provides information on tensile strength characteristics of pavement materials. Repeated load tests were conducted to study the effect of fly ash-based geopolymer coated aggregates in bituminous concrete, its fatigue characteristics, and permanent deformation. The dynamic shear rheometer test was performed to understand changes of rheological characteristics of binder influenced by fly ash-based geopolymer coating on the aggregates. The tests and their results are described in the following sections.

\subsection{Indirect tension test}

A higher tensile strength indicates better low temperature cracking resistance (Huang et al., 2005) [25].

Tensile characteristics of bituminous mixtures were evaluated by loading the Marshall specimen along a diametric plane with a constant compressive load parallel to and along the vertical diametrical plane of the specimen through two opposite loading strips. This loading conFigureuration developed a relatively uniform tensile stress perpendicular to the direction of the load and along the vertical diametrical plane, ultimately causing the specimen to fail by splitting along vertical diameter. A $13 \mathrm{~mm}$ wide loading strip was used for $101 \mathrm{~mm}$ diameter specimen to provide a uniform loading that produces a nearly uniform stress distribution. The static indirect tensile strength of specimens was determined using the procedure outlined in ASTM D 6931. A loading rate of 51 $\mathrm{mm} / \mathrm{minute}$ was adopted. The test equipment and sample breakdown are shown in Figure 7.

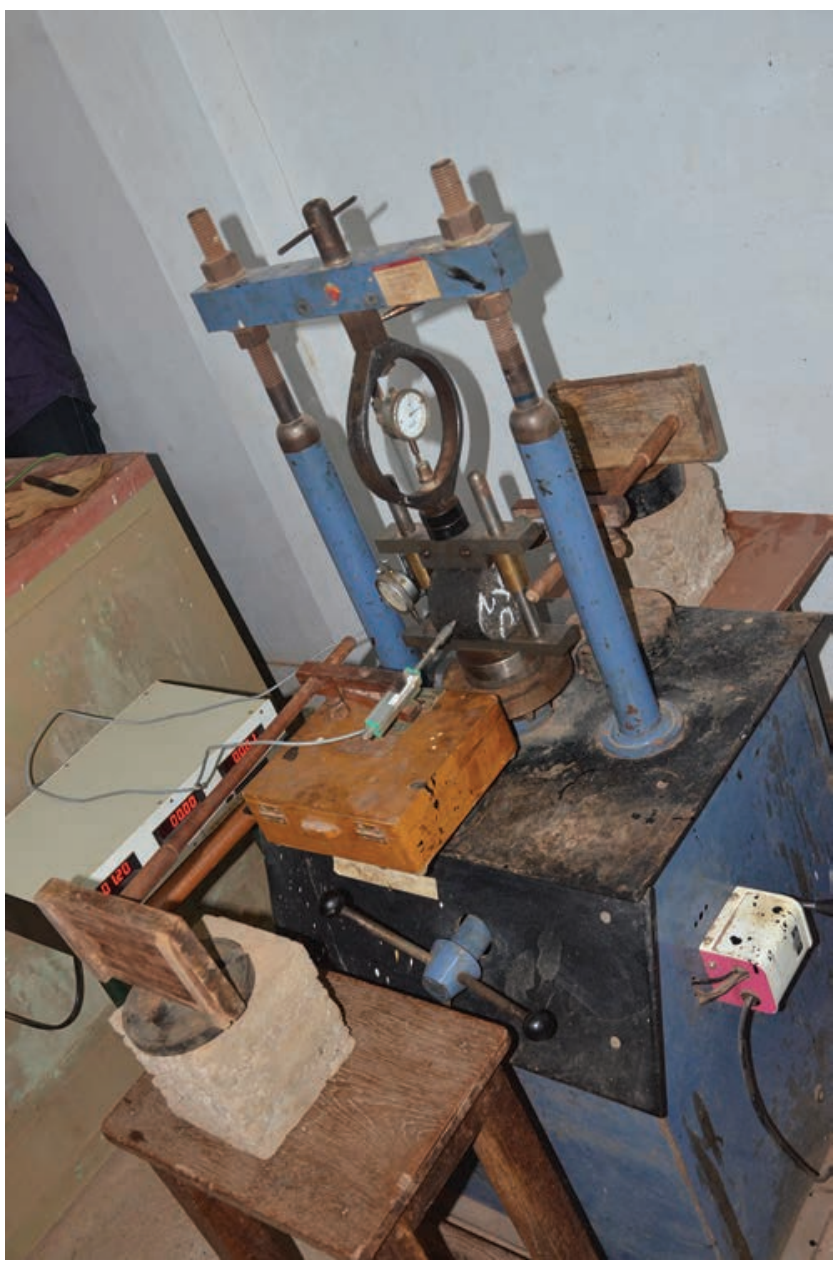

Figure 7. Indirect tension test

The tensile failure occurred in the sample. The peak load was recorded and divided by appropriate geometrical factors to obtain the split tensile strength using the following equation:

$$
\begin{array}{ll}
S_{t} & -2000 P / \pi t D \\
P & - \text { maximum load }[\mathrm{N}] \\
t & - \text { specimen height immediately before test [mm] } \\
D & - \text { specimen diameter [mm] }
\end{array}
$$

Table 10. Indirect tensile strength

\begin{tabular}{|c|c|c|c|c|c|c|}
\hline $\begin{array}{c}\text { Bitumen } \\
\text { content } \\
{[\%]}\end{array}$ & Bitumen mix & $\begin{array}{c}\text { IDT unconditioned } \\
{[\mathrm{kPa}]}\end{array}$ & $\begin{array}{c}\text { Horizontal strain } \\
{[\%]}\end{array}$ & $\begin{array}{c}\text { IDT conditioned } \\
{[\mathrm{kPa}]}\end{array}$ & $\begin{array}{c}\text { Horizontal strain } \\
{[\%]}\end{array}$ & \begin{tabular}{c} 
TSR \\
\hline 5.5
\end{tabular} \\
\hline Tip I & 662.4 & 6.2 & 433.2 & 5.3 \\
\hline 5.5 & Tip II & 792.7 & 8.6 & 643.5 & 5.4 & 0.81 \\
\hline 5.8 & Tip III & 864.6 & 9.4 & 739.6 & 6.2 & 0.86 \\
\hline
\end{tabular}


The specimens were prepared as discussed in Section 3.2 Tests were conducted at $25^{\circ} \mathrm{C}$ and the load was applied to failure at the deformation rate of $50.8 \mathrm{~mm}$ per minute. Horizontal deformation at failure was recorded by LVDT for different types of bituminous concrete mixes. The test setup and specimen failure are shown in Figure 7. The tensile strain at failure was determined using the indirect tension test. The test results are shown in Table 10. It was generally observed that the mixes prepared with the fly ash-based geopolymer coated aggregates exhibited better performance and higher tensile strength ratio. A high tensile strain is an indicator of better resistance to low temperature cracking. Compared to ordinary mixes with uncoated aggregates, type II and type III mixes exhibited a higher tensile strain confirming better crack resistance.

\subsection{Repeated load test}

The investigation was conducted by the repeated load indirect tensile test at test temperature of $25^{\circ} \mathrm{C}$ to determine the resilient modulus and fatigue life of designed bituminous concrete mixes. This test was selected because it can easily be conducted on Marshall specimens. Many researchers have used this test method to evaluate fatigue life of bituminous mixtures. Read [26] suggested that repeated load test results correlate to actual pavement service life much better than static creep tests. Shivangi Gupta and A. Veeraragavan [27] used this test to investigate the fatigue behaviour of SBS modified bituminous mixes.

The test was conducted using the repeated load testing equipment fabricated at the National Institute of Technology, Tiruchirappalli, India. In the scope of this test, a repeated load of fixed magnitude and cycle duration was applied diametrically to cylindrical test specimens with the help of a personal computer. A load of 1.40, 1.60 and $2 \mathrm{kN}$ was applied for a period of $0.1 \mathrm{~s}$ and the rest period of $0.9 \mathrm{~s}$ was given during the test until specimen failure. Cumulative permanent deformation as a function of the number of load cycles can be correlated to rutting potential of the test specimen. A total of 9 cylindrical Marshall specimens, 3 in each mix type, was prepared as discussed in Section 3.2. The specimens were tested to determine fatigue parameters. The resilient Poisson's ratio and resilient modulus were calculated using expressions proposed by Mohammad and Paul [28]. The test results are presented in Table 11.

It can be observed from the fatigue results that the resilient modulus of type II and type III mixes with fly ash-based geopolymer coated aggregates show higher values than the type I mix with uncoated aggregates. An increase of approximately 15.6 percent was noted for Type II. The type III mix, which was prepared using FA2 with a higher calcium oxide content, exhibits an increase of 38.8 percent compared to type I mix. Figures 10 and 11 show that bituminous mixes prepared using fly ash-based geopolymer coated aggregates

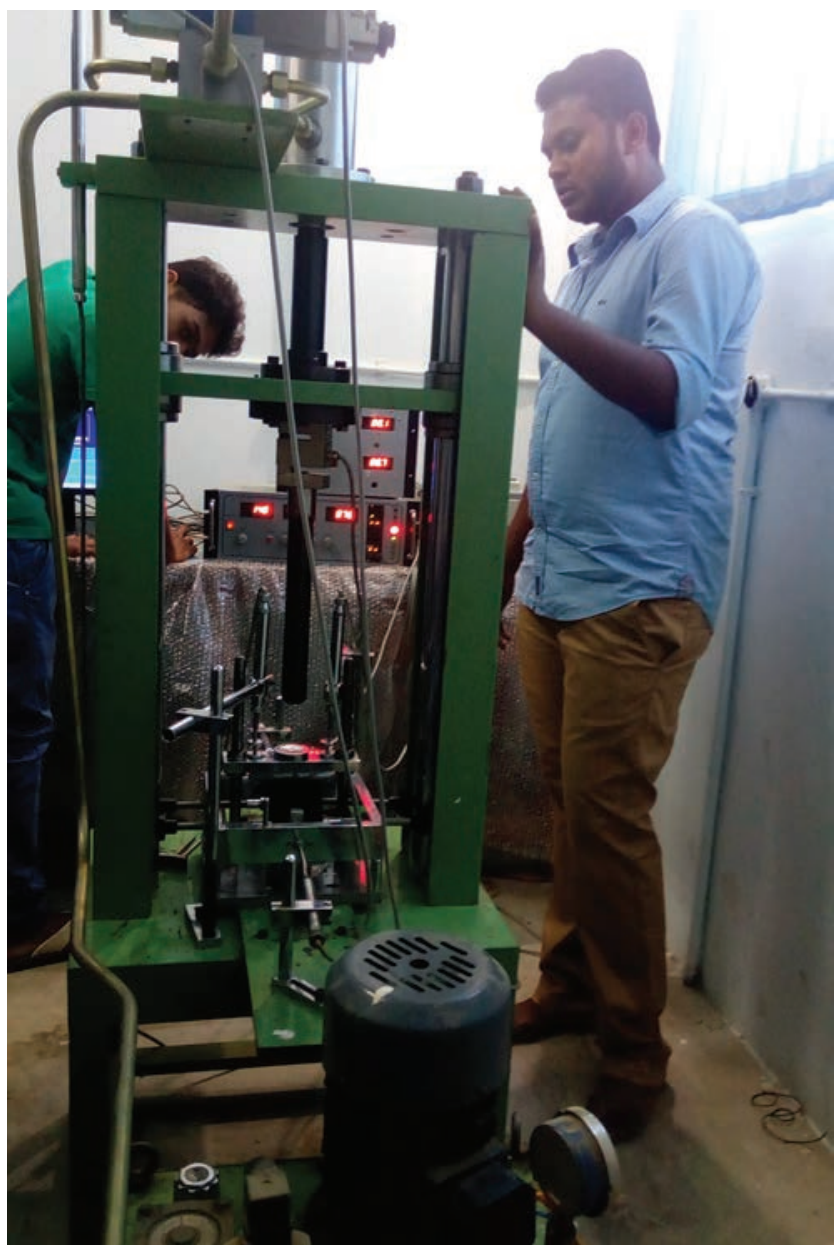

Figure 8. Repeated load test

Table 11. Repeated load results

\begin{tabular}{|c|c|c|c|}
\hline $\begin{array}{c}\text { Applied load } \\
{[\mathrm{kN}]}\end{array}$ & $\begin{array}{c}\text { Average } \\
\text { resilient } \\
\text { modulus } \\
{[\mathrm{MPa}]}\end{array}$ & $\begin{array}{c}\text { Fatigue life } \\
\text { (no of cycles) }\end{array}$ & $\begin{array}{c}\text { Initial tensile strain } \\
\text { (micro strain) }\end{array}$ \\
\hline \multicolumn{4}{|c|}{ MIX Type I } \\
\hline 1.4 & 44.47 & 952 & 127 \\
\hline 1.6 & 50.82 & 814 & 135 \\
\hline 2 & 63.53 & 238 & 157 \\
\hline 1.4 & 51.41 & 1313 & 91 \\
\hline 1.6 & 67.21 & 900 & 112 \\
\hline 2 & 73.33 & 334 & 127 \\
\hline & & \multicolumn{3}{|c|}{ MIX Type II Type III } \\
\hline 1.4 & 71.4 & 1521 & 53 \\
\hline 1.6 & 83 & 1112 & 77 \\
\hline 2 & 92 & 540 & 95 \\
\hline
\end{tabular}


exhibit an improved resistance to plastic deformation. It can be observed that all three mix types tested for permanent deformation follow the same pattern until failure, although an increased resistance in terms of cumulative horizontal and vertical deformation as a function of cycles was observed for type II and type III mixes, which reveals higher resistance to rutting.

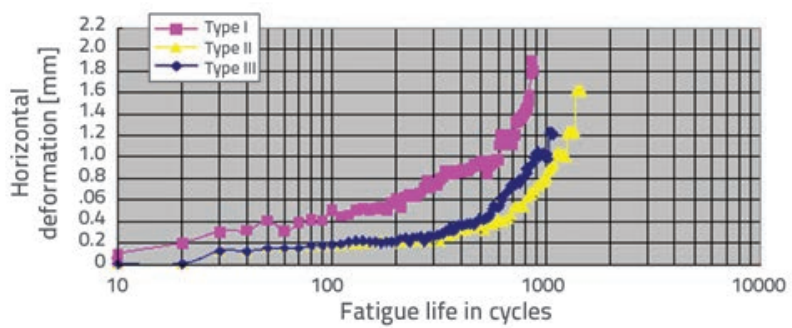

Figure 9. Relation between horizontal deformation and number of cycles for $1.4 \mathrm{kN}$

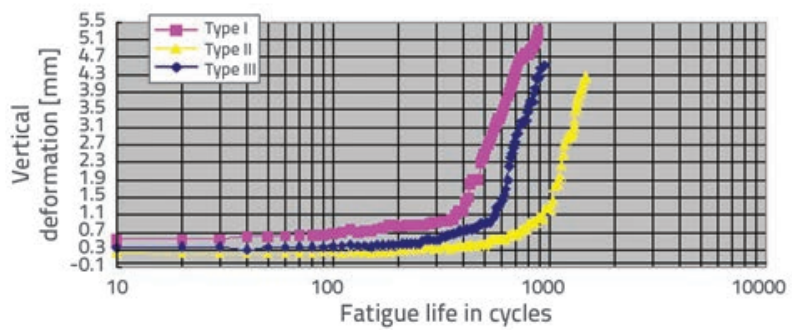

Figure 10. Relation between Vertical deformation and number of cycles for $1.4 \mathrm{kN}$

\subsection{Dynamic shear rheometer test}

Mechanical properties of bituminous mixtures directly depend on the properties of the binder. Bitumens are thermoplastic materials that exhibit highly elastic and brittle behaviour at low temperatures, while they are fluid and exhibit the ability to flow at high temperatures. At moderate temperatures they behave in a viscoelastic manner. This fundamental rheological property needs to be studied with regard to the use of binder in paving mixtures. The Dynamic Shear Rheometer (DSR) is a device that can be used to determine rheological characteristics of binder over wide range of temperatures and loading conditions.

This test was conducted in this study as per AASHTO T315, the objective being to gain further knowledge on the influence of the fly ash-based geopolymer adhering to the surface of aggregates. The bitumen used for type I mix was treated as neat bitumen (Sample 1). The bitumen was extracted from the type II (Sample 2) and type III (Sample 3) mixes as per Indian standard IRC SP11-1998. The bituminous concrete mixture was repeatedly washed and filtered with solvents (benzene) in the bitumen extractor. Then the recovery of bitumen was done using Abson method of distillation as per ASTM D1856. In this method, the solvent of bitumen and benzene was heated until all the benzene vaporized and the bitumen was collected in the container through condenser.

In this study, the bitumen performance grading was made to obtain the DSR values at high temperatures, using the $0.124 \mathrm{~mm}$ gap and conical plate $25 \mathrm{~mm}$ diameter setup, Thin bitumen sample was sandwiched between two plates, of which the lower one was fixed. The upper plate was allowed to oscillate back and forth across the sample at 10 rad per sec to create shearing action. Each unaged binder sample was measured for complex shear modulus $\left(G^{*}\right)$ and Phase angle $(\delta)$ starting from temperature of $62^{\circ} \mathrm{C}$ until failure. The test results are given in Table 12.

Table 12. Dynamic shear rheometer test results

\begin{tabular}{|c|c|c|c|c|c|c|c|}
\hline Sample & $\begin{array}{c}\text { Temperature } \\
{\left[{ }^{\circ} \mathrm{C}\right]}\end{array}$ & $\begin{array}{c}\text { Shear stress } \\
{[\mathrm{kPa}]}\end{array}$ & $\begin{array}{c}\text { Strain } \\
{[\%]}\end{array}$ & $\begin{array}{l}\text { Phase shift } \\
\text { angle }\end{array}$ & $\begin{array}{c}\text { G*/Sin } \delta \\
{[\mathrm{kPa}]}\end{array}$ & $\begin{array}{c}\mathbf{G}^{*} \mathbf{X} \operatorname{Sin} \delta \\
{[\mathrm{kPa}]}\end{array}$ & Remarks \\
\hline \multirow{3}{*}{ Sample 1} & 60 & 0.28398 & 11.98 & 86.78 & 3.063 & 3.057 & \multirow{3}{*}{$\begin{array}{l}\text { Sample passed test } \\
\text { temperature of } 69.8^{\circ} \mathrm{C} \\
\text { and failed at } 72{ }^{\circ} \mathrm{C}\end{array}$} \\
\hline & 66 & 0.18542 & 11.99 & 88.06 & 1.547 & 1.545 & \\
\hline & 72 & 0.09249 & 11.98 & 88.21 & 0.772 & 0.772 & \\
\hline \multirow{3}{*}{ Sample 2} & 60 & 0.48798 & 11.98 & 86.97 & 4.097 & 4.068 & \multirow{3}{*}{$\begin{array}{l}\text { Sample passed test } \\
\text { temperature of } 71.1^{\circ} \mathrm{C} \\
\text { and failed at } 72{ }^{\circ} \mathrm{C}\end{array}$} \\
\hline & 66 & 0.22098 & 12 & 88.08 & 1.843 & 1.841 & \\
\hline & 72 & 0.10741 & 11.99 & 88.83 & 0.896 & 0.896 & \\
\hline \multirow{4}{*}{ Sample 3} & 60 & 0.54688 & 12.96 & 86.98 & 4.407 & 4.417 & \multirow{4}{*}{$\begin{array}{c}\text { Sample passed test } \\
\text { temperature of } 72.38^{\circ} \mathrm{C} \\
\text { and failed at } 76^{\circ} \mathrm{C}\end{array}$} \\
\hline & 66 & 0.44087 & 11.98 & 88.21 & 2.464 & 2.464 & \\
\hline & 72 & 0.32654 & 11.98 & 88.21 & 1.882 & 1.878 & \\
\hline & 76 & 0.10651 & 11.99 & 88.24 & 0.877 & 0.877 & \\
\hline
\end{tabular}


It can be understood from Figure 11 that the complex shear modulus of the bitumen extracted from the type II and type III mixes is higher compared to the unmodified bitumen sample from type I mixture for all test temperatures. This indicates that there is an influence of the inorganic fly ash-based geopolymer on the binder. During analysis of the rutting parameter, $\mathrm{G}^{*} / \operatorname{Sin} \delta$, and the fatigue parameter, $\mathrm{G}^{*} \cdot \operatorname{Sin} \delta$, it was established that there was no significant increase between the samples.

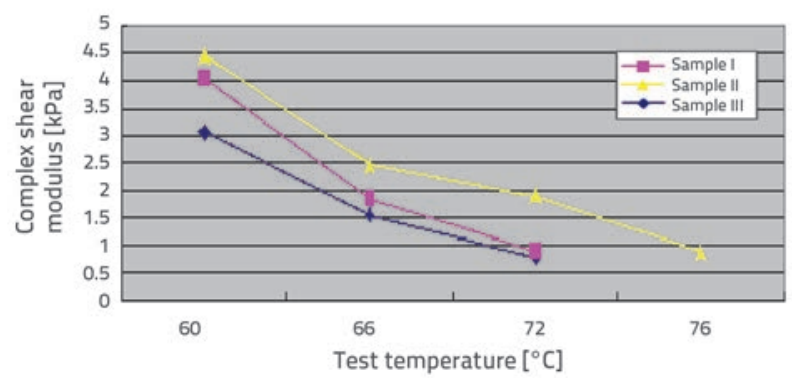

Figure 11. Complex shear modulus vs test temperature

\section{Conclusions}

Based on this study, the following conclusions can be made:

- The addition of fly ash-based geopolymer paste to natural aggregate enhances physical and mechanical properties of marginal aggregates, thus making them compliant with requirements for pavement construction.

- The SEM analysis shows a dense packed region of reacted particles in fly ash-based geopolymer prepared with fly ash having higher content of calcium oxide.
- The fluidity of geopolymer paste prepared with FA1 and FA2 decreases with an increase in molar concentration of sodium hydroxide.

- Geopolymers prepared with higher calcium content fly ash resulted in comparatively increased values of strength properties of aggregates in bituminous concrete mixtures prepared with fly ash-based geopolymer coated aggregates.

- Bituminous concrete mixtures containing fly ash-based geopolymer coated aggregates show better resistance to permanent deformation, which points to their higher potential rutting resistance and longer fatigue life.

- Dynamic shear rheometer test results for the extracted binder clearly indicate the influence of fly ash-based geopolymer on the binder, showing higher complex shear modulus with an increase in test temperature compared to the unmodified binder.

It can therefore be clearly inferred that the fly ash-based geopolymer can be used for coating natural aggregate to enhance its performance. Furthermore, the use of these coated aggregates in bituminous mixtures will contribute to better stability and longer service life of these mixtures, and can thus be a remedial measure for the disposal of fly ash.

\section{Acknowledgment}

The authors of this paper would like to express their gratitude to the Centre of Excellence of the Transportation Engineering Division, National Institute of Technology, Tiruchirappalli, India, for the financial support provided for the realisation of this study.

\section{REFERENCES}

[1] World Construction Aggregates, A research study by Freedonia Group, 2007, pp. 4, www.freedoniagroup.com

[2] Smith, P.: Demand of Aggregates in India, Aggregate Business International, 2013

[3] Kumar, P., Mehndiratta, H.C., Singh, V.: Use of fly ash in bituminous layer of pavement, Journal of Indian Highways, New Delhi, India, pp. 41-50, 2008

[4] Sharma, V., Chandra, S., Choudhary, R.: Characterization of Fly ash Bituminous Concrete Mixes, Journal of Materials in Civil Engineering, 22 (2010) 12, pp. 1209-1216, DOI: 10.1061/(ASCE) MT.1943-5533.0000125

[5] Rahman, M.N., Sobhan, M.A.: Use of Non-Conventional Fillers in Asphalt- Concrete Mixture, International Journal of Innovation and App.lied Studies, 3 (2013), pp. 1101-1109.

[6] Suheibani, A.S.: The Use of fly ash as an asphalt extender in asphalt concrete mixes, Ph.D thesis, University of Michigam, Ann Arboor, Mich. 1986

[7] Sobolev, K., Flores, Wasiuddin (Wasi), N.M.: The Use of Fly Ash as Filler in Asphalt Cement: Phase I, Final Report, UWM-WE Energies, pp. 17, 2011
[8] Solobev, K., Flores, I., Bohler, J.D., Faheem, A., Covi, A.: Application of fly ash in Asphalt Concrete: from Challenges to Opportunities, Review paper, University of Wisconsin-Milwaukee, USA, 2013.

[9] Sen, T., Mishra, U.: Usage of Industrial Waste Products in Village Road Construction, International Journal of Environmental Science and Development, 1 (2010) 2, pp. 122-126.

[10] Androjic, I., Kaluder, G., Komljen, M.: Usage of the Fly Ash in Hot Asphalt Mixes, The $28^{\text {th }}$ International Baltic Road Conference held on 26-28 Aug 2013 in Vilnius, Lithuania

[11] Davidovits, J.: Soft minerology and geopolymers, Proceedings of Geopolymer 88 International Conference, The Universite de Technologie, Compiengne, France, 1988

[12] van Jaarsveld, J.G.S., van Deventer, J.S.J., Lukey, G.C.: The Characterization of source materials in fly ash based geopolymer, Materials, Letter, 57 (2003), pp. 1272-1280.

[13] Xu, H., Lukey, G.C., van Deventer, J.S.J.: The activation of C class F- Fly ash and blast furnace slag using geopolymerization, In Eight CANMET/ACI International Conference on Fly ash, Silica Fume, Slag and Natural Pozzolans in Concrete, Las Vegas, NV, USA, 2009 
[14] Diaz, E.I., Allouche, E.N., Eklund, S.: Factors affecting the suitability of fly ash as source material for geopolymers, Fuel, 89 (2010), pp. 992-996.

[15] Wang, H., Li, H., Yan, F.: Synthesis and mechanical properties of metakaolinite - based geopolymer, Colloids and Surfaces $A$ : Physicochemical and Engineering Aspects, 268 (2005) 1-3, pp. $1-6$.

[16] Bakharev, T.: Thermal behaviour of geopolymers prepared using F Fly ash and elevated temperature curing, Cement Concrete Research Journal, 36 (2006), pp. 1134-1147.

[17] Temuujin, J., Riessen, A., van Mackenzie, K.J.D.: Preparation and characterisation of fly ash-based geopolymer mortars, Construction Building Materials, 24 (2010), pp. 1906-1910.

[18] Dutta, D., Chakrabarty, S., Bose, C., Ghosh, S.: Comparative Study of Geopolymer Paste prepared from Different Activators, Recent Trends in Civil Engineering and Technology, 2 (2012) 3, pp. 1-10.

[19] Xueying Li, XinweiMa, Shoujie Zhang, Enzu Zheng.: Mechanical Properties and Microstructure of Class C Fly ash-based Geopolymer Paste and Mortar, Materials, 6 (2013), pp. 14851495, http://dx.doi.org/10.3390/ma6041485, 2013

[20] Bayomi, F.M.: Development and Analysis of Cement - Coated Aggregates for Asphalt Mixtures - Effects of Aggregates and Mineral Fillers on Asphalt Mixture Performance' American Society for Testing and Materials, pp. 19-34, 1992

[21] Kamaruddin, I., Napiah, M.: Effect of Cement coated aggregates on the creep and deformation characteristics of asphaltic concrete bituminous mixtures, WIT Transactions on The Built Environment, 128 (2012), pp. 661-670.

[22] Kim, Y.R., Yim, N., Khosla, N.P.: Effect of aggregate type and gradation on fatigue and permanent deformation of asphalt concrete, ASTM STP 1147 (1992), pp. 310-328, http://dx.doi.org/ 10.1520/STP24225S 1992
[23] Kantha Kumar, K., Veeraragavan, A.: Optimizing the Bituminouc Concrete Mixes for Fatigue Performance, The open Construction Building Technology Journal, 2 (2008), pp. 53-58.

[24] Md. Kamal, H., Ullah, F.: Laboratory Evaluation of Lime Modified Asphalt Concrete mixes with respective to Moisture Susceptibility International Journal of Civil \& Environmental Engineering, 11 (2011) 54, pp. 45-52.

[25] Huang, B., Li, G., Vukosavljevic, D., Shu, X., Egan, B. K.: Laboratory investigation of mixing hot-mix asphalt with reclaimed asphalt pavement. Transportation Research Record 1929, Transportation Research Board, Washington, DC, pp. 37-45, 2005, https://doi. org/10.3141/1929-05

[26] Read, J.M.: Fatigue cracking of Bituminous Paving Mixtures,' Ph.D Thesis, University of Nottingham, Department of Civil Engineering, 1996

[27] Gupta, S., Veeraragavan, A.: Fatigue Behaviour of Polymer Modified Bituminous Concrete Mixtures, Journal of Indian Road Congress, 548 (2009), pp. 58-64.

[28] Mohammad, L.N., Paul, H.R.: Evaluation of Indirect Tensile Test for Determining Structural Properties of Asphalt Mix' Transportation Research Board, 1417 (1993), pp. 58-63, http://www.trb.org/ Publications/Pages/262.aspx, 1993

[29] Ministry of Road Transport and Highways (Fourth Revision, 2004), Specifications for Road and Bridge works, published by Indian Road Congress on behalf of Government of India

[30] ASTM D 6926 Standard Practice for Preparation of Bituminous Specimens Using Marshall App.aratus.

[31] ASTM D6927 Standard Test Method for Marshall Stability and Flow of Bituminous Mixtures

[32] ASTM D1075 Standard Test Method for Effect of Water on Compressive Strength of Compacted Bituminous Mixtures.

[33] ASTM D6931 Indirect Tensile Strength of Bituminous Mixtures 